\title{
HEMORAGIA CEREBRALĂ FETALĂ DIAGNOSTICATĂ ANTEPARTUM
}

\author{
Claudiu Mărginean', Lucian Puşcaşiu' ${ }^{1}$, Claudiu V. Molnar ${ }^{1}$, Florin Rozsnyai ${ }^{1}$, \\ Bela Szabo', Luminița Zahiu², Marta Simon², Manuela Cucerea², \\ Cristina Oana Mărginean ${ }^{3}$, Nicoleta Suciü ${ }^{4}$, Cosmin Rugină ${ }^{5}$ \\ ${ }^{1}$ Clinica de Obstetrică şi Ginecologie I, Spitalul Clinic de Urgență,Târgu-Mureş \\ ${ }^{2}$ Clinica de Neonatologie I, Spitalul Clinic de Urgență, Târgu-Mureş \\ ${ }^{3}$ Clinica Pediatrie I, Spitalul Clinic de Urgență, Târgu-Mureş \\ ${ }^{4}$ Universitatea de Medicină şi Famacie, Târgu-Mureş \\ ${ }^{5}$ Departamentul de Obstetrică şi Ginecologie, Spitalul Județean de Urgențăă, Piatra Neamț
}

\begin{abstract}
REZUMAT
Diagnosticul antepartum al hemoragiei cerebrale fetale (HCF) este mai puțin raportat (0,9/1.000 naşteri) comparativ cu cel postpartum. Sunt prezentate două cazuri de hemoragie intraventriculară fetală, diagnosticate ecografic antepartum.

Cazul 1: HCF diagnosticată ecografic la vârsta gestațională de 28 de săptamâni de gestație şi confirmată postnatal prin prezența în LCR a hematiilor (număr semnificativ, ratatinate) şi a modificărilor semnalate de ecografia transfontanelară (hidrocefalie internă severă, țesut cerebral minim). Decesul a survenit la 24 de ore postpartum (ex. histopatologic: hemoragie cerebrală intraventriculară). Menționăm absența aparentă a factorilor de risc materni, negativitatea testelor TORCH.

Cazul 2: hidrocefalie internă la vârsta de 37 de săptămâni de gestație şi confirmată la nou-născut (după cezariană) de modificările clinice caracteristice, suferința neurologică severă asociată cu modificări la ecografia transfontanelară şi aspectul hemoragic şi hipertensiv al LCR. Nu au fost depistați factori de risc materni. De asemenea, aparent nu au existat riscuri fetale: greutatea $2.820 \mathrm{~g}$ la 37 de săptămâni de gestație, teste TORCH negative, culturi şi CRP negative. Hidrocefalia a avut o evoluție progresivă impunând ventriculotomii şi cisternotomii; plasarea unui şunt ventriculo-peritoneal în timpul celei de-a treia intervenții neurochirurgicale a ameliorat prognosticul vital.

Concluzii. Prezența hidrocefaliei a fost un semn ecografic fidel pentru diagnosticul HCF. Evolutia şi prognosticul sunt influențate de severitatea hemoragiei şi de vârsta gestațională. Supraviețuitorii beneficiază de tratamentul neurochirurgical. Etiopatogenia plurifactorială, incomplet descifrată a HCF conduce la dificultăți în stabilirea unui grup țintă de screening, în scopul identificării acestei leziuni.
\end{abstract}

Cuvinte cheie: hemoragie cerebrală, diagnostic antepartum

\section{INTRODUCERE}

Hemoragia neonatală intracraniană este un fenomen bine cunoscut, mai ales la nou-născuții prematuri, la care cea mai frecventă este hemoragia ventriculară sau subependimală (1). Potrivit Vergani, incidența maximă este de 0,9/1.000 de cazuri, în sarcinile monitorizate (2). Clasificarea severității hemoragiilor intraventriculare fetale, inclusiv a celor neonatale, include: hemoragie de gradul I - definită ca fiind limitată la matricea subependimală; gradul II definită ca imagine de hemoragie ventriculară, cu mai puțin de $50 \%$ reumplere ventriculară laterală şi fără ventriculomegalie mai mare de 15 mm măsurată în atriu; gradul III - umplere de 50\% sau mai mare într-unul sau ambii ventriculi laterali, cu ventriculo-megalie, dar fără afectare parenchimatoasă evidentă, o ventriculomegalie de peste 15 mm fiind, de asemenea, inclusă în această categorie; gradul IV - manifestări cuprinse în gradele $1-3$, asociate cu imagine de hemoragie în parenchimul periventricular (3). Ecografia este cel mai important instrument în stabilirea diagnosticului de hemoragie intracraniană fetală. Semnele ecografice sugestive sunt: ventriculomegalie asimetrică, atro- 
fie talamică ipsilaterală, semne de sânge în lichidul cefalorahidian, zone ecogene neregulate în jurul ventriculilor sau ,focare ecogene“, hemoragie unilaterală în matricea germinală cu resorbție chistică (4). Aceste zone ecogene neregulate pot fi intraventriculare, periventriculare, subependimale, în parenchim, subdurale, şi intracerebelare. Rezonanța magnetică nucleară este o altă metodă importantă de diagnostic al hemoragiei intracraniane, care asigură o sensibilitate şi specificitate crescută față de ecografie. Tratamentul cazurilor severe implică de obicei intervenții neurochirurgicale cu plasarea unui şunt ventriculoperitoneal. În ceea ce priveşte formele uşoare, ele necesită de obicei doar monitorizare. Evoluția şi prognosticul hemoragiei cerebrale fetale depind de mai mulți factori, în special de severitatea hemoragiei.

\section{PREZENTAREA CAZURILOR}

Sunt prezentate două cazuri de hemoragie cerebrală fetală intraventriculară diagnosticate prin ecografie antepartum în Clinica de Obstetrică şi Ginecologie I din Târgu-Mureş pe parcursul a 5 ani.

Caz 1 - o gravidă în vârstă de 26 de ani, secundigestă şi secundipară, fără antecedente patologice relevante înainte şi în timpul sarcinii, monitorizată prin ecografie, cu ultima evaluare la 22 de săptămâni de gestație, care s-a prezentat la controlul de 28 de săptămâni. La începutul celui de-al treilea trimestru de sarcină, ecografia a evidențiat ventriculomegalie unilaterală, cu imaginea ventriculului cerebral lateral fetal cu aspect de ecogenicitate medie neregulată, sugerând tromb intraventricular şi tesut cerebral minim. După administrarea de steroizi, am efectuat operație cezariană, nou-născutul cântărind 1.200 de g, Apgar 4/1 minute. La puncția lombară efectuată la 6 ore postpartum s-au obținut peste 1.000 de eritrocite deformate/câmp microscopic în lichidul cefalorahidian şi s-a confirmat hemoragia intraventriculară din faza intrauterină. Ecografia transfontanelară a confirmat hidrocefalia internă severă grad 4 [conform clasificării Lustig Gillman (3)], cu țesut cerebral minim. Evoluția nou-născutului intubat în unitatea de terapie intensivă nou-născuți a fost nefavorabilă, cu decesul acestuia la 24 de ore postpartum, prin asociere cu boală severă a membranelor hialine. Testele TOR$\mathrm{CH}$ au fost negative.

Caz 2 - o femeie gravidă în vârstă de 26 de ani, la prima sarcină, fără antecedente patologice, cu o sarcină monitorizată ecografic, fără modificări la 33 de săptămâni de gestație, s-a prezentat la contro-
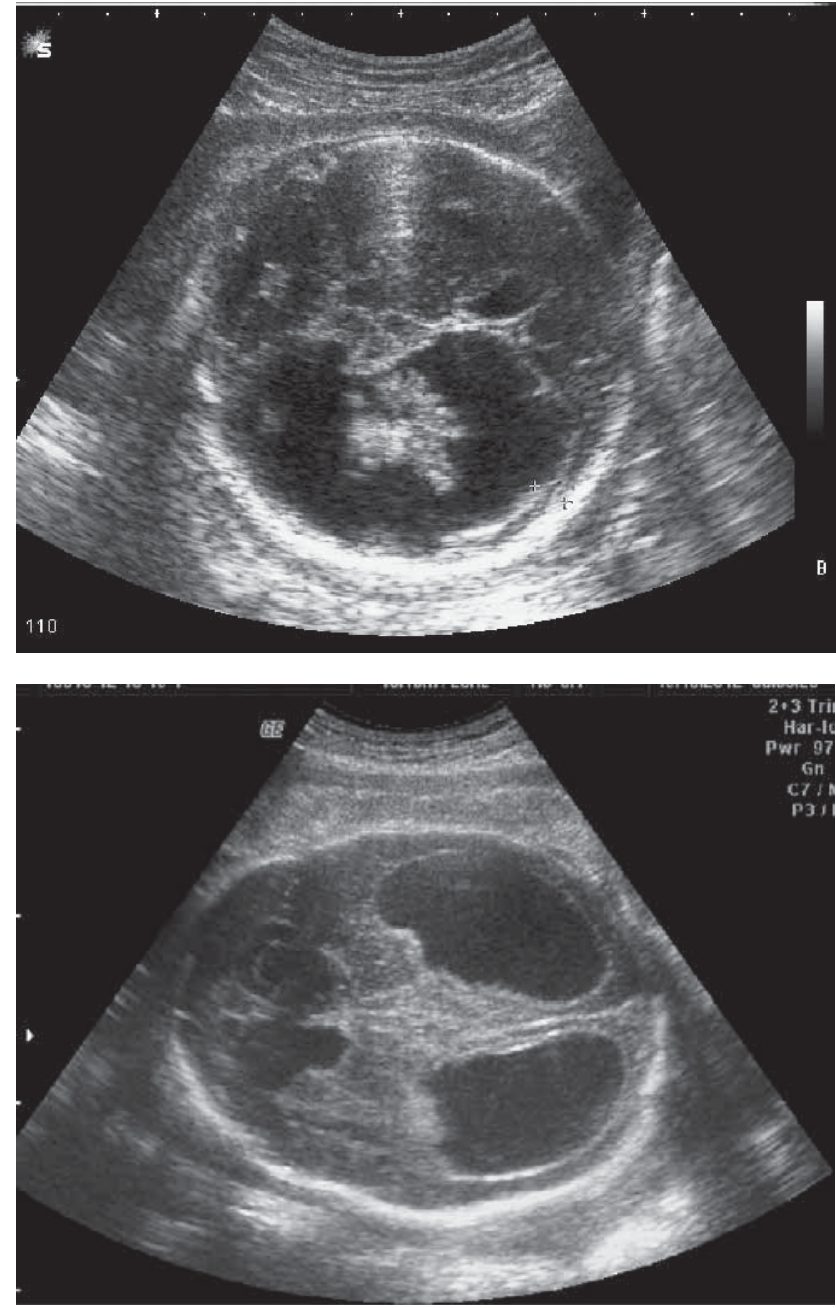

FIGURA 1. Cazul 1 (imaginea de sus) şi cazul 2 (imaginea de jos) - ecografie secțiune axială craniană fetală ventriculi laterali dilatați şi imagine neregulată cu ecogenicitate medie - hemoragie intraventriculară

lul periodic de rutină la 37 de săptămâni. Ecografia fetală a pus în evidență o hidrocefalie internă, imagine cu ecogenicitate moderată, neregulată în ventriculul lateral şi prezentare pelviană a fătului. La 24 de ore fătul s-a născut prin cezariană. Scorul Apgar a fost 9/1 minute cu macrocefalie, perimetru cranian de $38,5 \mathrm{~cm}$, greutate la naştere de $2.820 \mathrm{~g}$, fontanela anterioara $5 \times 6 \mathrm{~cm}$, fontanela posterioară $1 \times 5 \mathrm{~cm}$, ambele în tensiune cu suturi dehiscente, nou-născut cu tonus şi reflexe depreciate, reactivitate diminuată. Ecografie transfontanelară - hemoragie intraventriculară dreaptă grad 3 [conform clasificării Lustig Gillman (3)], hidrocefalie secundară (diametrul mediu al ventriculului lateral drept $2,6 \mathrm{~cm}$, stâng $2,0 \mathrm{~cm}$, diametrul ventriculului al treilea $0,7 \mathrm{~cm}$, indicele de rezistivitate al arterei cerebrale anterioare $>1$. Puncția lombară de evacuare şi diagnostic efectuată imediat postpartum pune în evidență lichid cefalorahidian hemoragic hipertensiv, cu un număr de 117.600 eritrocite/câmp, 514 leucocite/câmp, examenul bacteriologic al lichidu- 
lui cefalorahidian fără creştere bacteriană, testul TORCH, hemocultura şi CRP negative. Evoluția în următoarele 3 luni a fost cu hidrocefalie progresivă şi hipertensiune intracraniană, pacientul suferind 2 ventriculotomii şi cisternotomii. S-a plasat şunt ventriculoperitoneal în timpul celei de-a treia intervenții neurochirurgicale în afara țării, cu evoluție favorabilă până în prezent (ultimul control la vârsta de 3 ani).

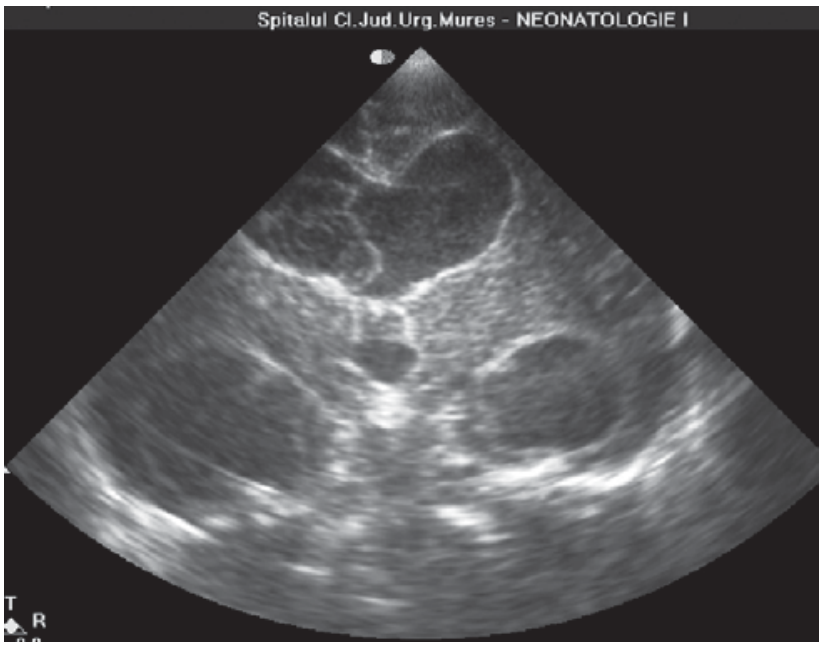

FIGURA 2. Cazul 2 - ecografie postnatală transfontanelară în secțiune coronală cu ventriculomegalie evidentă a cornului occipital al ventriculilor lateral şi al ventriculului 3

\section{DISCUȚII}

Etiologia hemoragiei intraventriculare neonatale este legată de: factori intravasculari - controlul presiunii microcirculației din matricea germinală, fluctuații în fluxul cerebral care duc la afectarea funcției placentare şi coagulării; factori vasculari legați de matricea microcirculației, locul hemoragiei iniţiale, afectarea maturizării vaselor matriceale cu ischemie; factori extravasculari - factori mezenchimali şi de suport glial pentru vasele matriceale implicate în activitatea fibrinolitică şi proteolitică a matricei germinale (5). Factorii incriminați care predispun la hemoragie intracraniană fetală sunt: materni - trombocitopenie idiopatică sau autoimună, boala von Willebrand, utilizarea de warfarine sau cocaină, convulsii, traumatisme abdominale severe care implică fătul, amniocenteza, colestaza de sarcină, boli febrile sau factori fetali - deficiente ale factorilor de coagulare $\mathrm{V}$ şi $\mathrm{X}$, hemoragii tumorale, sindrom de transfuzie de la un geamăn la altul, sarcina multiplă cu făt mort, hemoragie feto-maternă $(6,7)$. Într-o trecere în revistă a literaturii de specialitate a 47 de cazuri, Özduman consideră că jumătate dintre hemoragiile intracerebrale fetale sunt datorate trombocitopeniei autoimune sau traumatismelor (8). Cele două cazuri prezentate mai sus nu au prezentat nici trombocitopenie autoimună, nici traumatisme. Un studiu efectuat pe un grup de 113 feți a pus în evidență o asociere între hemoragia intracraniană fetală şi întârzierea creşterii intrauterine, în aproximativ 13\% dintre cazuri (9), dar în cazurile prezentate de noi nu am găsit aceste relații. Gould et al (10), în 2005, au descris pentru prima dată, la şoareci, mutația genetică ce poate duce la hemoragie cerebrală ,in utero“, şi anume mutația genei COL4A1, cunoscută în codificarea colagenului 4A1 (10). COL4A1 este o genă care codifică lanțul alfa - 1 al colagenului de tip IV, o proteină de membrană, care se găseşte pe scară largă în toate țesuturile, inclusiv vasele sanguine. Se pare că deprecierea acestei proteine predispune la hemoragie (11-13). Cu toate acestea, implicarea acestei mutații în etiologia hemoragiei intracraniene fetale rămâne neclară conform celor 2 cazuri prezentate de Garel: primul făt cu hemoragie intraventriculară şi întreruperea sarcinii la 30 de săptămâni de gestație, iar al doilea cu amniocenteză şi făt cu aceeaşi mutație, dar fără nicio tulburare până la vârsta de 9 luni postpartum (14). Hidrocefalia este considerată cel mai frecvent semn ecografic asociat cu semne de hemoragie intraventriculară subependimală (15). Cazurile care fac obiectul acestei prezentări au fost diagnosticate prin ecografie în timpul vieții intrauterine şi ambele au prezentat hidrocefalie. Vergani et al. (2) au analizat semnificația clinică a hemoragiei intracraniene fetale (41 de cazuri) şi au corelat evoluţia nefavorabilă cu: hemoragii parenchimatoase (12/13), subdurale şi subarahnoidiene (7/8). Hemoragiile intraventriculare au un prognostic uşor mai bun (11/20). Într-o altă serie de 4 cazuri de hemoragie intraventriculară de gradul 3 şi 4, diagnosticate „,in utero“ moartea perinatală s-a produs în 3 din 4 cazuri. Cel de-al 4-lea a avut o evoluție normală după plasarea unui şunt vetriculoperitoneal (4). Şuntul ventriculo-peritoneal a influențat favorabil evoluția imediată a cazului 2 , născut cu greutatea de 2.820 g la 37 de săptămâni de gestație.

\section{CONCLUZII}

Prezența hidrocefaliei a fost un semn ecografic fidel pentru diagnosticul HCF. Evoluția şi prognosticul acestor leziuni depind de severitatea hemoragiei şi de vârsta gestațională. Supraviețuitorii beneficiază de tratament neurochirurgical. Etiologia plurifactorială şi parțial neclară a acestei tulburări fetale, conduce la dificultatea stabilirii unui grup ,țintă“ de screening, în scopul identificării acestor leziuni. 